\title{
DO YOU “(MIS)UNDERSTAND” WHAT I MEAN? PRAGMATIC STRATEGIES TO AVOID COGNITIVE MALADJUSTMENT
}

\author{
Jesús ROMERO-TRILLO* \\ Autonomous University of Madrid
}

ELIZABETH LENN

The Graduate Center, City University of New York

\begin{abstract}
This article studies misunderstanding as a key factor in identifying the psychological basis of interactional cognitive maladjustment. The study focuses on the linguistic strategies to avoid pragmatic misunderstanding employed in conversations in Spanish and English and between native and non-native speakers of English. In particular, we analyze the use of pragmatic markers as adaptive management to avoid misunderstanding in conversation. Through the classification of pragmatic markers as rhetorical or overt, we study the distribution and use of each type of pragmatic marker and the implementation of pragmatic markers, with the lexical and intonational implications in cross-linguistic conversation for the adaptive Management of misunderstanding.
\end{abstract}

Keywords: Pragmatic markers, adaptive management, intonation, understanding, intercultural communication, maladjustment.

\footnotetext{
Correspondence should be sent to: Dr. Jesús Romero-Trillo. Departamento de Filología Inglesa. Facultad de Filosofía. Universidad Autónoma de Madrid. We are grateful to the Ministerio de Ciencia e Innovación, project FFI2009-08395.
} 


\title{
¿(NO) COMPRENDES LO QUE TE QUIERO DECIR? ESTRATEGIAS PRAGMÁTICAS PARA EVITAR LA MALA ADAPTACIÓN COGNITIVA
}

\begin{abstract}
RESUMEN. El presente artículo analiza la falta de comprensión como elemento clave en la identificación de la ausencia de adaptación cognitiva en la interacción. El estudio se centra en las estrategias lingüísticas que evitan la falta de comprensión pragmática en conversaciones en lengua inglesa y española, y en la conversación entre hablantes nativos y no nativos de inglés. En concreto, analizamos el uso de los marcadores pragmáticos como elementos de gestión adaptativa para evitar la falta de comprensión. Mediante la clasificación de los marcadores pragmáticos en retóricos o explícitos, estudiamos la distribución y uso de cada marcador pragmático y su implementación, teniendo en cuenta las implicaciones léxicas y entonativas de la conversación entre hablantes de diferentes lenguas maternas a la hora de adaptar la falta de comprensión.
\end{abstract}

Palabras clave: Marcadores pragmáticos, gestión adaptativa, entonación, comprensión, comunicación intercultural.

Received 18 January 2011

Revised version accepted 13 June 2011

\section{INTRODUCTION}

Conversation can be described as a habitual social activity in which participants choose to share thoughts, ideas and feelings with others. The description of conversation with a prominent orientation towards the analysis of the formal features related to its structure has attracted many scholars for the past 35 years, as described for instance by Sacks, Schegloff and Jefferson (1974) and other conversation analysts. In more recent times, a second approach has tried to decipher the cognitive relationship between cognitive processes and meaning, as for example in the works by Panther and Thornburg (1998), Ponterotto (2000), and others. The present study proposes a third approach that focuses on the role of the cognitive component insofar as it justifies the verifiable correct transmission of knowledge through linguistic data. This third approach will try to describe the psychological status of interaction behind the speakers' turns through the study of misunderstanding as a key factor to identify interactional cognitive maladjustment.

The notion of misunderstanding has been traditionally linked to the lack of semantic adequacy in the emission or reception of the content of a message. This phenomenon, denominated 'semantic misunderstanding', has been the subject of study by conversation analysis who have delved into this phenomenon and into its corresponding solution often described as repair strategies (Schegloff et al. 1977). However, there is another type of conversational breakdown that we shall 
call "pragmatic misunderstanding". "Pragmatic misunderstanding" can be defined as the distance between the pragmatic expectations of the recipient of a message and the actual pragmatic force of that message.

Pragmatic misunderstanding is conceived in our description as an anomalous result in the communication process that mars or disrupts the structural fluency of the interaction but is not definite in its impossibility to re-route the mutual understanding of the participants. As mentioned above, some solutions to the appearance of semantic misunderstanding have been described through the concept of "repair", although sometimes the pervasive use of this notion has led scholars to take for granted that repair is an unavoidable, all purposeful, and universal phenomenon in conversation, as Power \& Dal Martello (1986) have criticized.

The aim of this study is to focus on the linguistic strategies to avoid pragmatic misunderstanding employed in casual conversations in Spanish, in English, and between native and non-native speakers of English. The study will describe the types of misunderstandings, the levels of language at which it exists, and how and when pragmatic markers participate in the repair cycle and become essential elements to avoid pragmatic misunderstanding.

\section{THEORETICAL BACKGROUND}

Grice's description of the Cooperative Principle in which he states that linguistic exchanges are "cooperative efforts; and each participant recognizes in them, to some extent, a common purpose or set of purposes, or at least a mutually accepted direction" (1975:49-50) is possibly the best starting point to illustrate the importance of the correct meaning transmission in a conversational exchange. However, even while following the cooperative maxims or rather submaxims, quantity, quality, relation and manner, a breakdown in communication may occur and the speaker must enact a strategy in order to repair, or preferably avoid, the misunderstanding through a pragmatic strategy. Theoretically, the strategies employed to manage pragmatic misunderstanding respond to the philosophical underpinnings of misunderstanding itself, specifically, how the misunderstanding arose and who can or will recognize the misunderstanding and initiate the repair. Misunderstandings arise due to multiple linguistic (phonological, syntactic, semantic, pragmatic) and non-linguistic (contextual, cultural) reasons and many studies have delved into their classification, even with emphasis on the interaction across cultures (House 2000).

This study emphasizes a prior stage and analyses the circumstances that surround the speaker's awareness of how his/her contribution can avoid pragmatic misunderstanding. Therefore, pragmatic misunderstanding constitutes an earlier 
moment in the process of miscommunication between speaker and hearer than the more traditional notions in the study of cross-cultural communication of "pragmatic error" (Riley 1989), or "pragmatic failure" (Thomas 1983). In fact, from our perspective pragmatic misunderstanding is less onerous for the interactional fluency of a conversation than 'pragmatic error', which leads to an incorrect assumption about the pragmatic status of the message, or 'pragmatic failure', which implies a complete breakdown in the social liaison between the speakers.

Pragmatic misunderstandings occur in all types of conversations, also between native speakers of the same language, and do not necessarily need to be explained in terms of cultural gaps, but in relation to the cognitive processing of information. Obviously, this processing requires different strategies depending on the interlocutor as regards age, cultural background, sex, ethnic origin, mother tongue, etc. but it is interesting to notice how often speakers of the same language and background fall in the trap of pragmatic misunderstanding even more easily than speakers of different languages and origins. In this sense, we could argue that pragmatic misunderstanding is sometimes the result of habit or lack of attention rather than a question of cultural impairment or linguistic deficiency.

In a classical study Dascal (1999: 754) states that misunderstanding is "a communicative phenomenon typically belonging to reception, occurring at the semantic-pragmatic layers of communication, having to do with incorrectness rather than with non-ethical behavior and being involuntary". This implies that misunderstanding is ubiquitous, and so are the mechanisms employed to repair misunderstanding. Theoretically, according to Dascal (op.cit.), misunderstanding is almost always immediately detected and then repaired. In a second stage, when a misunderstanding remains unresolved after several turns, it is then labeled miscommunication as described in Weigand's words: a "breakdown in communication caused by sustained misunderstanding" (cf. Dascal 1999: 754).

The point at stake once miscommunication occurs is how to manage the situation and we can find different accounts to this problem. For Trognon and SaintDizier, misunderstanding management is a "trouble-shooting process...recognized, and resolved...[within] the framework of their 'interlocutionary' approach" (Dascal 1999: 754-755), while Bazzanella and Damiano (1999: 818) prefer to focus on the management of misunderstanding by naming the levels of linguistic repair as phonetic, syntactic, lexical, semantic and pragmatic. Their research studies the repair of misunderstanding in terms of the formal aspects of the process: the author of the repair; the phases of negotiation; the collocation of the repair; linguistic and non-linguistic understanding.

From a theoretical perspective, we find two approaches on the relationship between misunderstanding and communication: the linguistic and the discoursephilosophical. The first is more concerned with the down-to-earth linguistic and 
conversational approach to misunderstanding, as proposed by Dascal (1999) who distinguishes four potential elements in the analysis of misunderstanding:

1. Production versus reception misunderstanding.

2. The linguistic 'layer' or 'level' of misunderstanding, which includes lexical semantics, stylistic choices, and pragmatics.

3. The social norms on which the evaluation of misunderstanding is based.

4. Involuntary versus voluntary misunderstanding. (Dascal 1999: 753-754)

On the other extreme we can find the discourse-philosophical approaches to this phenomenon, as for example Garand (2009: 473) who concludes that misunderstanding is not an accident of local communication but rather an inherent feature of dialogue. Garand (2009: 474) departs from Habermas' ethical premise of communication based on the principle that any conversation presupposes a desire to establish consensus. Garand's study, which uses a socio-philosophical approach to the "I" and "We" in conversation, like Weizman (1999), focuses on that misunderstanding that degenerates into conflict. Garand studies elements of conversation that may be influenced by intent (enunciation, for example), thus disrupting the Cooperative Principle or the Habermasian idea of pursuit of consensus. Garand's study extends a step beyond our study, which focuses on ways to avoid misunderstandings when they unintentionally occur.

A middle way between both models can be found in Schegloff (1987: 202), who states that since languages are built for effortless understanding, communication between people who belong to different communities or different cultural backgrounds will encounter misunderstandings, and this type of conversation will lead to non-standard misunderstanding. Also, Weigand (1999: 764-66) discusses four possibilities of misunderstanding as non-standard cases in communication: the cross-cultural case, communication as miscommunication (as in the origin of arguments and disputes), and misunderstanding in a harmonious model that builds content on this phenomenon (as humorous interactions).

In the same vein, Moeschler (2004: 50) uses a cognitive approach to study nonstandard cases of misunderstanding, specifically intercultural misunderstanding. Moeschler believes that within intercultural communication the greatest risk of misunderstanding comes when the non-native speaker has a strong mastery of the primary language in the interaction, as the native speaker will assume that the non-native speaker also has the cultural grounding of the language. Using the ostensive-inferential approach of Sperber and Wilson's (1995) Relevance Theory, Moeschler examines how misunderstanding occurs in various intercultural settings. The assumptions of native speakers and the pragmatic implications of their conversations with non-native speakers result in misunderstanding. 
This is precisely one of the sections of our study in which we will examine how pragmatic markers are used in intercultural communicative cases to repair misunderstanding.

\section{ADAPTIVE MANAGEMENT: A MODEL TO PREVENT PRAGMATIC MISUNDERSTANDING}

Although the models presented above account for the main features of misunderstanding and repair, we believe that they mainly focus on the origin, behaviour and results of misunderstanding from a linguistic, cultural and even philosophical stance, but little is said about the role of misunderstanding prevention in the course of communication. In our model, this function is realized by "Adaptive Management" (Romero-Trillo 2007, Romero-Trillo and Maguire 2011) as it guarantees the functioning of conversation through self-organization to avoid systemic breakdown. Adaptive Management has been defined as "the capacity of a speaker to adapt the grammatical, lexical and pragmatic parameters of discourse through a series of remedial elements and through a principled process, in order to comply with the demands of a new cognitive stage in a conversation via a cognitive standardised process" (Romero-Trillo 2007: 83).

In other words, we believe that there is no such question as pragmatic failure in communication when the linguistic code is shared, but a process of adaptation that guides the cognitive -and therefore the linguistic- management of a concept until understanding is complete. In this model, the concepts flow through the structure of the message aided by some linguistic elements whose behaviour aims at threading the interactional network on which the cognitive process hangs and moves forward.

Although several linguistic elements can act in the process of Adaptive Management, this article will concentrate on Pragmatic Markers as basic elements that speakers use to avoid pragmatic misunderstanding.

In the classification of Pragmatic Markers in Adaptive Management we can find two types of discourse behaviour: Overt and Rhetorical.

- Overt Pragmatic Markers: "do you know what I mean?"; they explicitly seek to maintain interaction through cognitive metalinguistic verification.

- Rhetorical Pragmatic Markers: "you know, you see, I mean"; they do not require a response from the listener and take correct cognitive reception for granted, they seek rapport in what Romero-Trillo (2001) calls the Sympathetic Circularity Function.

(Romero-Trillo 2007:84-85) 
Overt and rhetorical Markers will be used in everyday discourse for different purposes and with different statistical representation. However, the distribution of overt versus rhetorical in Spanish and English language users, and additionally in comparison with the usage in conversation between native and second-language learners, magnifies the difference in usage and purpose of these two types of markers. This is concomitant with Aijmer's conclusions on the effects of mis-use of pragmatic markers by non-native speakers which are "less significant but certainly far less easy to resolve than the incorrect use of a content word" (cf. Hansen 1998: 199).

Pragmatic Markers are, then, the primary focus of the strategies to avoid misunderstanding as they serve to mould the cognitive stance of the speaker-hearer relationship according to the pragmatic force of an utterance in a given context. In the Adaptive Management model, Pragmatic Markers function in a triangulation fashion in which the addressor, addressee and the message are in continuous feedback that is essential in the orientation of the cognitive processing of the addresser (the production processing) and addressee (the reception processing) as well as in the textual processing of the message itself as an individual entity (Romero-Trillo, in press).

The examples were selected from the 'Corpus de referencia del español actual (CREA)', the London Lund Corpus, and the LINDSEI Corpus, as well as conversations recorded between native English speakers and second-language proficient speakers of English ${ }^{1}$.

\section{ANALYSIS OF THE DATA}

As mentioned above, the distinction between Overt and Rhetorical Pragmatic Markers is related to intonation (question vs. statement pitch movement) as an indicator of the possibility given to the addressee to respond to the marker. In other words, Overt Markers give the recipient the power to judge the processability of the message by responding to the confirmation posed by the marker. Usually, this possibility is only practised in the case of misunderstanding, while silence or feedback signals are symptomatic of the correct reception of the message (Romero-Trillo 2001).

\subsection{NATIVE SPANISH EXAMPLES}

The Overt Markers selected for Spanish are ‘Me entiendes?' (do you understand) and 'iMe explico?' (Do I explain myself?). Both look similar but trigger different impressions on the speaker. The former, 'iMe entiendes?', can be classified as a Face

\footnotetext{
1 The corpora have been selected because of their representative value in the sociolinguistic data that the authors wanted to investigate.
} 
Threatening Act (Brown and Levinson 1987) directed to the addressee to check if Adaptive Management is necessary. Often this is characteristic of unbalanced conversation in terms of power relations, but also we have noticed it appears in the speech of speakers unaware of politeness strategies who believe that lack of understanding is always a fault of the addressee's. The other expression, ' $\mathrm{Me}$ explico?' is always considered more polite as it mainly puts the responsibility of the hypothetical misunderstanding on the speaker and a negative answer would not be so face threatening.

In fact, the typical basic form ¿Me explico? is the only one that appears in the interrogative form as in the following example:

- Alguna acción en la cual haya sido inconsecuente, ¿me explico? Entonces tenemos que pensar tenemos...

(Any action in which I have been inconsistent, do you understand what I mean? So we have to think...)

However, the corresponding Face Threatening forms 'Entiendes?' (do you understand?) offers more variation as an indicator of how different politeness strategies might be used depending on the situation. We can differentiate between those questions in which there is the personal pronoun 'me' as an object, which suggests a more emotional approach, for example in the ubiquitous 'MMe entiendes?' (do you understand me?):

- para mi hija. Claro, eso sí supongo que ¿Me entiendes? Testigo y fruto de esa Exacto. Unión...

(for my daughter. Yes, I suppose so, do you understand what I mean? Witness and as a result of this, exactly, Union...)

And the neutral form:

- estado volando también el plan de las municipales, ¿entiendes? O sea que Yo be ido también en esa dirección.

(flying in the municipal plan, understand? So I've gone in that direction.)

And the same with the Direct Object that refers to the content of the message:

- bambú, borla borla, borla borla, bambú bambú. ¿Lo entiendes? Bambú bambú, borla borla, borla borla...

(bambú, borla borla, borla borla, bambú bambú. Do you understand it? Bambú bambú, borla borla, borla borla...) 
There are interesting combinations that tone down the force of the message by taking for granted the understanding but are followed after a slight pause by the equivalence to a question tag with rising intonation.

- días y y y te la daré ya toda completa". Me entiendes, ¿no? Y, tengo, pues pues equipos habia...

(days and I'll give it to you all together." You understand me, right? And I have, well, the teams had...)

Also, there are also combinations that include the personal approach and the emphatic metalinguistic comment to what is being said:

- en esta casa no entra ni mi padre ni mi madre, eme entiendes lo que te digo? ¿Por qué? Porque mi madre e...

(Neither my father nor my mother comes to this house, do you understand what I'm saying? Why? Because my mother is...)

- ¿entiendes lo que te quiero decir? O sea, yo no es que...

(Do you understand what I'm trying to say? Or, it's not that...)

What unites all these markers is that in the majority of cases the recipients of the message do not respond to the questions. In other words, the speakers choose these markers to prevent misunderstanding and emphasize their polite (or less polite) attitude towards the addressee before any communication breakdown takes place.

In the case of rhetorical markers we find combinations that are shared by both 'explico' and 'entiendes' forms. This is an interesting fact because these kinds of markers do not depend so much on politeness or on questions related to the emotional state of the participants. This is reflected linguistically in their affirmative intonation contour, as they do not trigger any response or feedback in the addressee and allows the speaker to continue with the development of the message. In fact, most of these rhetorical devices are often used to reformulate a concept or idea. In other words, we can say that they are more semantically oriented.

The typical combinations for 'explico' are the following:

- ¡Bueno! Pues esta cubeta tiene una restricción, me explico, quiere decir de que tú cuando abres la el...

(Good! Well, this cell has a restriction, what I mean is, I want to say that when you open the...)

- por qué siguen? Bueno, están curados... a ver si me explico, están curados fisicamente. 
(why continue? Well, they are cured, what I mean is, they are physically cured.)

- los caballos de batalla hoy mayor. Voy a ver si me explico. Sí, cortito. Me dice Iñaki que muy corto.

(The workhorses from today were older. Let me see if I explain. Yes, short. Iñaki said very short.)

- arriba Quizás te impide continuar. No sé si me explico. Sí, absolutamente, se encasilla le encas ** ---

(above may prevent you from continuing. I don't know if I'm being clear. Yes, absolutely, it's classified---)

- persona y no te has dado cuenta de ella. No sé si me explico, quiero decirte. Si, sí, es decir, la...

(person and you have not been aware of her. I don't know if you understand, I want to say, yes, yes, to say, the...)

The Rhetorical combinations for 'entiendes' are the following:

- era, ¿me entiendes? porque a lo mejor no sé si me entiendes lo que te quiero decir, Tere. Es un niño ta...

(was, do you understand? Because, I don't know if you understand what I'm trying to say, Tere. It's a boy, ta...)

- tapón, que igual está flojo. Eso es, a ver si me entiendes, yo no tengo la culpa de si la botella imp...

(stopper, which is equally weak. That is, let's see if you understand me, that it's not my fault if the bottle imp...)

To sum up, Spanish mainly uses two Pragmatic Markers to initiate repair prevention in the process of Adaptive Management: 'explico' and 'entiendes' and a plethora of variants such as 'ya me entiendes, a ver si me entiendes, si es que me entiendes', etc... Both kernel forms can appear in the overt and rhetorical function, although the overt is perceived as more direct and even aggressive in some cases.

\subsection{NATIVE ENGLISH EXAMPLES}

The first interesting fact is that English does not favour the use of lexically transparent elements to indicate understanding. After a search in the English London-Lund Corpus (consisting of 50,000 words) we did not find any instances of pragmatic markers that resemble the Spanish expressions presented above, even with semi-literal translations such as: 'am I making myself clear?/do I make myself clear?', or of anything near to 'Am I explaining myself?/do I explain myself?'. 
English seems to prefer the discourse markers 'you know', 'you see' (addresseeoriented) and 'I mean' (speaker-oriented), to start Adaptive Management. What is important to notice is that the elements with 'you' can appear with a rising, level or falling intonation, while the 'I' marker mostly appears with falling or level contour (rhetorical function), and with interrogative contour only in marginal cases (2.22\% of the markers in the London-Lund Corpus). This is interesting in comparison with the Spanish examples because it shows that the enactment of Adaptive Management does not question the validity of the speaker, but rather puts the weight of the responsibility of understanding on the addressee. In other words, the communication process in this respect is more a question of correct understanding than of accurate explanation.

Here follow some examples of 'I mean' from the London-Lund Corpus with three possible tones: falling $(\backslash)$, rising $(/)$ and level (=):

- A ^how !easily 'taken /in\# /

$\mathrm{B} \wedge[\backslash \mathrm{m}] \# /$

A I $\wedge^{\wedge} \mathrm{m} /$ ean\# . /

A to $\wedge$ have a 'student 'come to you and $[\mathrm{s}]-((\mathrm{oh})) /$

- $\quad$ B $\wedge$ I've been cam!p \aigning for th/at\# /

B for $\wedge$ several !y $\backslash$ ears $\mathrm{n} / \mathrm{ow} \#$ /

$\mathrm{B}$ and in $\wedge \backslash$ any_case $\left\{\mathbf{I} \wedge^{\wedge} \mathrm{m} \backslash\right.$ ean $\# \# \#$. /

$\mathrm{B} \wedge$ why !!sh $\backslash$ ould we $\{\wedge$ test the two things /

- B well it`s $\wedge$ sort of !t $\backslash$ oo . $\wedge y \backslash$ es\# /

B *it`s*/

A *I*^m=ean\# /

A it $\wedge$ would _be a 'bit 'out of !pl $\backslash$ ace *s/omehow\#* /

What is important in the behaviour of 'I mean' is that even in the cases when it appears with rising intonation it does never hint at the possibility of receiving an answer, in other words, rising tone does not realise the overt function for this pragmatic marker.

It is also interesting that sometimes 'I mean' appears without tone, what Romero-Trillo (1994) described as tone 0. This 'tone' appears at the end of a tone group and indicates lack of expectancy of response from the addressee.

- $\quad \mathrm{B} * \wedge((\text { th } \backslash \text { at's 'not } \mathrm{b} / \mathrm{ad} \#))^{*} /$
A *but $\wedge_{\text {where* }}$. it`s $\wedge$ so ! b $\backslash$ ig $\{\backslash$ isn`t 'it\#\}\# /
$B$ it`s $\wedge$ gi!g $\backslash$ antic $\left\{\wedge \backslash\right.$ isn`t $*^{*}$ it $\# * * \# /$
$\mathrm{B}\left(\left(\mathrm{I}^{\wedge}\right.\right.$ mean $\left.)\right) /$ 
Perhaps this lack of specificity in its function as an overt marker makes it prone to appear in combination with any of the other two markers, 'you know, you see', to acquire this function (a resource that does not appear in Spanish). We can say that there is a cumulative rhetorical effect that merges the addresseeoriented and speaker-oriented Adaptive Management strategy, as in the following example:

- $\quad$ B at [dhi] . the ! $1 \backslash$ iterature\# - /

B I mean you know the ^actual !st \atements\# -

B [@:m] I $\wedge$ don`t think they`ve . they :ever in :fact /

The examples with 'you see' also show that this marker can appear with the four possible intonation contours (rising, falling, level, and 0), with the interesting fact that the use of the marker in the overt function can be followed by the answer of the interlocutor certifying that understanding is correct as in the following example. This obviously contrasts with the previous use of the rising tone by 'I mean' that does not function as a true overt Adaptive Management element:

- $\quad \mathrm{B}$ or $\wedge$ tw $\backslash \mathrm{O}$ we $`$ ve *got on th/ere\#*/

B ^you s/ee\#/

A *^yes !I s $\backslash$ ee\#*

A $\wedge$ y=es\#

As mentioned above, 'you see' with the Rhetorical function can appear with tone 0 , as in:

- A but $\wedge$ only from :Kyd \onwards\# /

A so that you see I $\wedge$ didn`t even do : $\backslash$ any $\{\wedge$ Old /

A $\backslash$ English\#\}\# /

Or with falling and level tones, as in the following examples:

- A but $\wedge_{\mathrm{n} \backslash \mathrm{O}}$ /

A $\wedge$ you s $\backslash$ ee '[@:m]\# . /

$\mathrm{A}[@] \wedge \mathrm{n} \wedge \mathrm{O}^{\#} /$

- B ((you know [@m])) $\wedge_{\mathrm{v}} \wedge$ ery 'few ‘women\# /

B [@m] . ^you s=ee\# /

$\mathrm{B} \wedge$ women : $\mathrm{d} \backslash$ /entists\# / 
Although all tones are possible with the marker 'you see', it is important to mention that there is a prevalence of the use of this marker with the Overt function, $44.83 \%$ of the cases, which indicates a specialization in the distribution and the interrogative resonance that it might create in the speakers.

The case of 'you know' is similar to 'you see', in as far as it can appear with the Overt function, as in the example below:

- $\quad$ A he was $\wedge$ sitting in a $: \mathrm{c} \backslash$ /orner\# /

$$
\text { A } \wedge y \backslash \text { es\# / }
$$

A and [@m] . you ^kn/ow\# /

A $\wedge$ came up and intro!d $\backslash /$ uced him'self\# - /

And with the Rhetorical function:

- A $\wedge$ this 'is a $v \backslash$ ery 'bad th/ing\# /

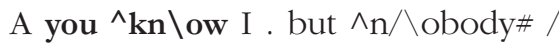

A could do $\wedge /$ anything $\{\mathrm{a} \wedge \mathrm{b} / \backslash$ out it $\# \#$ \#

- $\quad$ B which $\wedge$ have to $b=e \#-/$

$\mathrm{B}$ you ${ }^{\wedge} \mathbf{k n}=\mathbf{o w} \#$ /

$\mathrm{B} \wedge$ put into :W $\backslash$ ood $\# /$

As in the case of 'you see', this marker shows a preference for the Overt function, with $63.2 \%$ of the cases.

\subsection{ENGLISH NATIVE SPEAKERS IN CONVERSATION WITH SPANISH SPEAKERS OF ENGLISH AS A FOREIGN LANGUAGE}

After the description of the mechanism of Adaptive Management in the prevention of misunderstanding by native speakers of Spanish and English, our article now focuses on the mixed interactions in English with native and nonnative speakers. The first interesting observation is that in our data most of the pragmatic markers used to are overt (87.5\%). This gives a first hint as to the characteristics of this type of interaction: speakers are afraid of misunderstanding and use clear signals to verify the correct reception of the message. The use of comprehension questions in Adaptive Management tend to disrupt the rhythm of the conversation as there are frequent changes of the speaker at points that would not be necessary if native speakers were participating in the conversation. This also creates a sense of insecurity in the non-native speakers if native speakers at some point may choose to keep the habitual pace in turn-taking with much fewer confirmation checks. 
Also, most examples reproduce full-fledged lexical expressions with accurate questions such in the following example:

- A: People will live on tiny little houses on the beach, and young people will come to work on the beach more or in restaurants, or work on the ferry. Do you know what a ferry is?

B: Yeah, like a ship.

Or in other cases, given the fact that one part of the message was not understood, and in fact was assumed as being clear by the speaker, what we have is a correction request by the addressee and then a lexical explanation that, in any case, contains another comprehension check:

A: And we were able to talk about Christmas Carols and Caroling and vocabulary and-

B: And who?

A: Caroling-it's the verb, for Christmas Carol...you can make a verb, like singing, but singing carols. It's called Caroling.

B: Uhm.

A: Do you know what carols are?

B: No.

A: Christmas songs. The songs you sing at Christmas are called Carols.

B: They call them carols?

A: Yes. So, caroling is singing the song.

B: Ah, I didn't know what. I didn't know that.

In this type of mixed interactions Adaptive Management is rarely realized by any of the typical pragmatic markers used in native speaker interactions ('I mean, you see, you know'), but it is managed through clear expressions that are semantically transparent and, as the interlocutor is linguistically disadvantaged, there are not usually concerns about face threatening situations:

- A: Why? Why? And the other 30 minutes?

$\mathrm{R}$ : The idea is that you should be guiding the class...do you understand? Guiding the class?

A: Yeah.

R: Guiding the class, more than just talking to them.

In fact, we have examples of direct requests for clarification by the non-native speaker, as in 
- A: Rapids, like a rapid? Ok...

B: Explain to me?

A: Are you kidding? Do you know what a rapid is?

Or in the following cases in which the first request, 'sorry', is not considered and the listener has to formally confess lack of understanding:

- A: do you think she'll give him a tip?

B: sorry

A: do you think she'll give him a tip

B: I don't understand you sorry

A: do you think that she will give the painter a tip for such a good painting

And:

- A: so you just went to visit pretty much

B: sorry

A: you just went to visit pretty much right

B: I... I don't understand

A: [you just went to visits . like ah . a vacation

B: yes . yes

It is interesting to notice that in these last examples the word 'sorry' is uttered by the Spanish speakers as an Adaptive Management signal to indicate lack of understanding, however, the native speakers in both cases interpret that there has been a lack of perception of the message, not of the content, so the non-natives have to resort to the very clear 'I don't understand' to ask for clarification.

These examples show that Adaptive Management to avoid misunderstanding between native and non-native speakers of English takes place mainly at the lexical level and is activated not through pragmatic markers but through repetitions or clear requests for clarification. In some cases, the words that may cause confusion are vocabulary words that the learner may not have learned or has forgotten due to underuse, e.g., 'rapid', or 'carol', or with concepts such as 'tipping', which is much more prevalent in the United States than in Spain. In most cases, the giver of information recognizes immediately which word or term is causing confusion and uses various techniques, starts Adaptive Management and avoids misunderstanding.

Sometimes the native speakers resort to metalinguistic tools to start Adaptive Management, as in the following examples: 
- A: Discourse. Discourse is sort of like, uhm, not sure of the exact definition but it's sort of like what people talk about, but the meaning behind what people talk about. Do you know what I mean? It's kind of like the discourse of a society.

B: OK.

- A: So, Spain, "We're all White, there's no Moorish blood, we're all Catholic," you know what I mean. So a lot of nations are built upon a certain discourse, the US, "We're all free...,"

In the case of the non-native speakers it is very important to mention that they do not generally use Adaptive Management in any form that may resemble the Spanish markers. In fact, they try to imitate the way native speakers speak to them when they use Adaptive Management resources, sometimes mirroring the way they are addressed for clarification, as in the following examples:

- definitely I mean it must be really hard to know that . to be that age and still . be ready to like. I don't know die some day so <laughs> . but em .. I don't know maybe if they did know they could prevent .. giving it to anybody else . you know what I'm saying $<\backslash A>$

Or,

- And uhm, you think they are so rejected? Actually? Or is more the way they feel, because they maybe they are..., they feel, how do you say that? Away too long from home? Do you understand what I mean?

We have seen that most of the times non-natives try to imitate the way native speakers use Adaptive Management between themselves, as in:

- I learnt . that eh you can't pretend. to be what you're not . I mean you can't you can't pretend . being . twenty-two . when you are twenty-nine . you know you . well I'm already I'm . I've been twenty-nine . on the fourth of April so it's not so <begins laugh> so terrible yet <ends laugh>

And in the following interaction between a native speaker (A) and a nonnative $(\mathrm{B})$ :

- B: but you feel better because you .. you see them . laugh and you see them . you know go out of their .. of their . environment .. because it's .. it's horrible some of them come from broken . families or 

A: $\mathrm{mhm}$
B: just .. you know horrible things like that so
B: and we decided to do something - you know for . just to . to make some other people happy you know they get really tired and . they they miss their homes but $<\backslash \mathrm{B}>$

It is also remarkable that non-native speakers sometimes use a combination of markers, as native speakers do, although the cumulative elements in most of the cases are redundant, as opposed to the 'I mean' with another marker that is used to make this marker functionally overt, as explained above. The reason may be that, contrary to Spanish, Adaptive Management in these cases is more 'pragmatic' in its realization while in Spanish is more 'lexical', i.e., more transparent:

- B: and $s=$ because he thinks he is going to resurrect or something like that . but. the the even the end of the of the of the film you expect it . you . you know what's going to happen and . everything . there's a the . the the the the wife of the of the of Christopher Lambert . eh you know that's going something is going to happen to her <laughs> you see ... you know what I mean em em em.

\section{CONCLUSIONS}

The results of our study show that English and Spanish show different strategies for Adaptive Management to avoid misunderstanding. In fact, the study confirms that Spanish uses more lexically-based pragmatic markers while English makes more use of pragmatic strategies based on intonation parameters (Romero-Trillo and Newell: forthcoming).

The study has also shown that overt and rhetorical markers have different functions in conversation and that this difference is especially clear in English, in which most of the uses of the markers 'you know' and 'you see' are overt (interrogative), and that the 'I mean' examples are mainly rhetorical. This dissociation is not so clear in Spanish, which seems to prefer rhetorical markers to start Adaptive Management.

This balance is disrupted in mixed English conversations by native and nonnative speakers as in this case the natives abandon pragmatic markers for Adaptive Management and resort to repetitions, clarifications, and transparent comprehension checks that disrupt the pace of the conversation and make interaction almost infantile, especially when the concepts that need explanation are lexical. We can say that it is not the Adaptive process itself but its realization that becomes dense. This contrasts with the behaviour of non-natives who try to emulate native 
speakers in their Adaptive Management and use pragmatic markers almost nativelike. The result of this unbalanced combination between native speakers who behave 'uvuncularly' and non-natives who do their best to sound native-like is an interaction with disruptive rhythm that loses freshness and pragmatic vigour. In general terms, according to our results we think that there is a challenge for native speakers to predict and manage misunderstanding prevention when they engage in conversation with non-native speakers to create a cognitive scenario that portrays authentic interaction and information management.

\section{REFERENCES}

Aijmer, K. 2002. English discourse particles: Evidence from a corpus. Studies in Corpus Linguistics. Amsterdam and Philadelphia: John Benjamins.

Bazzanella, C. \& R. Damiano. 1999. "The interactional handling of misunderstanding in everyday conversations." Journal of Pragmatics 31: 817-836.

Brown, P. and S. Levinson. 1978. Politeness. Cambridge: Cambridge University Press.

Dascal, M. 1999. "Introduction: Some questions about misunderstanding." Journal of Pragmatics 31: 753-762.

Garand, D. 2009. "Misunderstanding: A Typology of Performance." Common Knowledge 15: 472-500.

Grice, H.P. 1975. "Logic and conversation." Syntax and semantics: III. Speech acts. Eds. P. Cole and J.L. Morgan. New York: Academic Press. 41-58.

Hansen, M.B.M. 1998. The function of discourse particles. A study with special reference to spoken standard French. (Pragmatics and Beyond New Series 53). Amsterdam and Philadelphia: John Benjamins.

House, J. 2000. "Understanding misunderstanding: A pragmatic-discourse approach to analysing mismanaged rapport in talk across cultures." Culturally speaking Managing rapport through talk across cultures. Ed. H. Spencer-Oatey. London: Continuum. 146-164.

Moeschler, J. 2004. "Intercultural Pragmatics: A Cognitive Approach.” Intercultural Pragmatics 1: 49-70.

Panther, K.U. and L. Thornburg. 1998. "A cognitive approach to inferencing in conversation." Journal of Pragmatics 30: 755-769.

Ponterotto, D. 2000. "The cohesive role of cognitive metaphor in discourse and conversation." Metaphor and Metonymy at the Crossroads, a Cognitive Approach. Ed. A. Barcelona. Berlin: Mouton de Gruyter. 283-298. 
Power, R.J.D. and M.F. Dal Martello. 1986. "Some criticisms of Sacks, Schegloff and Jefferson on turn taking." Semiotica 58: 29-40.

Riley, P. 1989. "Well don't blame me! - On the interpretation of pragmatic errors." Contrastive pragmatics. Ed. W. Oleksy. Amsterdam: John Benjamins. 231-249.

Romero-Trillo, J. 1994. "Ahm, Ehm,... You call it theme? A thematic approach to spoken English.” Journal of Pragmatics 22: 495-509.

Romero-Trillo, J. 2001. "A mathematical model for the analysis of variation in discourse." Journal of Linguistics 37: 527-550.

Romero-Trillo, J. 2007. "Adaptive management in discourse: the case of involvement discourse markers in English and Spanish conversations." Catalan Journal of Linguistics 6: 81-94.

Romero-Trillo, J. In press. "Pragmatic markers." The Encyclopedia of Applied Linguistics. Oxford: Wiley-Blackwell.

Romero-Trillo, J and L. Maguire. 2011. "Adaptive Context, the fourth element of meaning." International Review of Pragmatics 3: 226-239.

Romero-Trillo, J and J. Newell. Forthcoming. "Prosody and feedback in native and non-native speakers of English". In Romero-Trillo, J. (ed) Pragmatics, Prosody and English Language Teaching. Dordrecht: Springer.

Sacks, H., Schegloff, E. and G. Jefferson. 1974. "A Simplest Systematics for the Organization of Turn-Taking for Conversation." Language 50: 696-735.

Schegloff, E. 1987. "Some Sources of Misunderstanding in Talk-in-Interaction." Linguistics 25: 201-218.

Schegloff, E., Jefferson, G. and H. Sacks. 1977. "The preference for self-correction in the organisation of repair in conversation." Language 53: 361-382.

Sperber, D. and D. Wilson. 1995. (2nd ed.) Relevance: Communication and Cognition. Oxford: Blackwell.

Thomas, J. 1983. "Cross-cultural pragmatic failure." Applied Linguistics 4: 91-112.

Weigand, E. 1999. "Misunderstanding: The standard case." Journal of Pragmatics 31: $763-785$.

Weizman, E. 1999. "Building true understanding via apparent miscommunication: A case study." Journal of Pragmatics 31: 837-846. 